\title{
Pengaruh Modul E-Jas Edutainment terhadap Karakter Peduli Lingkungan dan Tanggung Jawab
}

\author{
Savitri Wanabuliandari, Sekar Dwi Ardianti \\ savitri.wanabuliandari@umk.ac.id, sekar.dwi.ardianti@umk.ac.id \\ FKIP Universitas Muria Kudus
}

\section{The Influence of E-Jas Edutainment Modules towards Environmental Awareness and Responsibility Character}

\begin{abstract}
The purpose of this research was to: (1) find out the influence of E-JAS edutainment thematic module on environmental awareness character, and (2) find out the influence of $E$ JAS edutainment thematic module on the character of responsibility. The type of research used is quasi experiment, with the population of this research of fourth graders of SD Negeri in Kudus Regency. The research subjects were students of four grade in SD 2 Jati Kulon, District Jati, the Regency of Kudus in the academic year 2017/2018. The sampling technique was done by purposive sampling. The research design was one group pre-post test. The data collection techniques were non-test techniques through interviews and observation. Data analysis techniques which determine the effect of E-JAS edutainment module on environmental awareness character and responsibility used paired samples T-test. The result of this research was (1) there was an influence of E-JAS edutainment module towards environmental awareness character, and (2) there was an influence of E-JAS edutainment module towards the character of responsibility.
\end{abstract}

Keywords: E-JAS Edutainment module, environmental care, responsibility

$\begin{array}{ccc}\text { Article Info } & \\ \text { Received date: } 16 \text { Oktober } 2017 & \text { Revised date: } 21 \text { November } 2017 \quad \text { Accepted date: } 19 \text { Desember } 2017\end{array}$

\section{PENDAHULUAN}

Saat ini, pemerintah sedang fokus dalam menanamkan pendidikan karakter. Melalui pendidikan karakter diharapkan akan muncul generasi muda yang berakhlak mulia. UU Nomor 20 tahun 2003 pada pasal 3 dijelaskan bahwa berakhlak mulia merupakan salah satu komponen penting dalam berbangsa serta bernegara. Akhlak mulia selalu berkaitan dengan karakter dan watak. Pendidikan karakter bisa ditempuh melalui pendidikan formal dan informal. Tanpa pendidikan karakter, seseorang dapat berbuat apa saja walaupun merugikan orang lain. Oleh karena itu, pendidikan karakter hendaknya mulai ditanamkan sejak dini agar terbentuk generasi muda yang berakhlak mulia.

Salah satu karakter yang harusnya mendapatkan perhatian adalah karakter peduli lingkungan dan tanggung jawab. Akbar (2010) menjelaskan ada beberapa permasalahan di sekolah dasar yang harus segera ditangani yaitu berkaitan dengan masih rendahnya karakter peduli lingkungan peserta didik serta karakter tanggung jawab pada peserta didik. Permasalahan tersebut dikarenakan kondisi Indonesia yang saat ini sedang mengalami krisis lingkungan. Laporan dari World Resources Institute (Barbier, 2015), Indonesia merupakan negara urutan ke 6 sebagi penghasil emisi karbon tertinggi di dunia. Menurut Pun (Blacksmith Institute dan Green Cross Swiss, 2013) sungai Citarum yang berada di Indonesia merupakan satu dari sepuluh sungai tercemar di dunia. Bahkan penelitian dari Marlina, dkk (2015) menjelaskan bahwa pada tahun 2050 polusi lingkungan menjadi penyebab kematian utama. Hal ini tidak boleh terus berlanjut, oleh karena itu perlu adanya tindakan pencegahan sejak dini. 
Salah satu bentuk pencegahan yang perlu dilakukan adalah melalui pendidikan. Melalui pendidikan, penanaman karakter peduli lingkungan dan tanggung jawab dapat diwujudkan. Hal ini senada dengan Uno,dkk (2011: 136) yang menyebutkan bahwa menanamkan kesadaran dan pemahaman tentang pentingnya menjaga lingkungan dapat dilakukan melalui pendidikan. Pendidikan karakter peduli lingkungan dan tanggung jawab dapat dimulai dari sekolah. Uyoh (2010:141) menyebutkan bahwa di sekolah peserta didik aktif untuk mempelajari berbagai hal yang berkaitan dengan lingkungan, serta memiliki dorongan untuk berbuat sesuatu terhadap lingkungannya. Sekolah terutama di SD merupakan tempat yang paling baik dan awal dalam menanamkan karakter tanggung jawab dan peduli lingkungan. Usia peserta didik di Sekolah Dasar adalah antara 6-13 tahun, mereka memiliki karakteristik yang cenderung menyukai seseorang yang dapat dijadikan idolanya. Oleh karena itu, sebagai seorang guru hendaknya memiliki kepribadian yang dapat dijadikan teladan dan idola bagi peserta didiknya. Hal ini dapat dilakukan melalui penanaman karakter peduli lingkungan dan tanggung jawab di berbagai kesempatan.

Berdasarkan hasil wawancara dengan guru di SD 2 Jati Kulon didapatkan informasi bahwa sebenarnya penanaman karakter peduli lingkungan sudah coba dilakukkan oleh sekolah melalui kegiatan jum'at bersih. Selain itu, telah dibentuk regu piket yang setiap paginya membersihkan kelas. Akan tetapi, dalam pelaksanaanya masih belum maksimal. Ini terlihat dari hasil observasi peneliti di SD 2 jati Kulon dimana terlihat dari masih banyak peserta didik yang kurang peduli terhadap lingkungan serta tidak bertanggung jawab terhadap tindakannya seperti membuang sampah tidak pada tempatnya, hal tersebut dilakukan tidak hanya di dalam kelas tetapi juga di luar kelas. Berdasarkan hasil angket yang disebar ke 10 peserta didik di SD 2 jati Kulon menunjukkan bahwa 9 dari 10 peserta didik membuang sampah sembarang karena malas sedangkan 6 dari 10 peserta didik membuang sampah semabarangan karena tidak ada yang mengawasi. Sebanyak 5 dari 10 peserta didik tidak mengetahui dampak tidak peduli terhadap lingkungan, sedangkan 8 dari 10 peserta didik tidak mengetahui cara mengelola dan memanfaatkan sampah. Pada observasi awal yang telah peneliti lakukan didapatkan hasil skor rata-rata pretest karakter peduli lingkungan adalah 51,58 sedangkan skor rata-rata karakter tanggung jawab adalah 45,07. Hal ini menunjukkan karakter peduli lingkungan dan tanggung jawab peserta didik masih kurang.

Salah satu cara yang dapat diterapkan untuk mengatasi kurangnya karakter peduli lingkungan dan tanggung jawab adalah melalui bahan ajar berupa modul. Modul yang dikembangkan adalah modul E-JAS edutainment . Melalui bantuan modul, guru mampu merancang kegiatan pembelajaran yang dapat mengikutsertakan peserta didik untuk aktif berperan dalam kegiatan pembelajaran. Menurut Parmin, dkk (2012: 8) modul merupakan komponen penting dalam pembelajaran karena digunakan untuk membantu memperoleh informasi materi pelajaran. Kelemahan dalam pemakaian modul adalah munculnya rasa jenuh pada peserta didik sehingga diperlukan inovasi dalam pengmbangan modul agar modul dapat menarik bagi peserta didik serta menyenangkan dalam pemakaiannya sesuai dengan amanat pada kurikulum 2013.

Pembelajaran tematik dan terpadu merupakan salah satu amanat pada kurikulum 2013. Hal ini tertuang dalam Permendikbud No. 65 Tahun 2013 berkaitan dengan standar proses dalam Kurikulum 2013. Keterpaduan dalam kurikulum 2013 maksudnya adalah adanya kaitan antar KD dari suatu mata pelajaran sehingga dapat memunculkan beberapa tema dalam kegiatan pembelajaran. Keterpaduan memberikan efek positif bagi peserta didik salah satunya kegiatan pembelajaran semakin efisien, efektif serta semakin bermakna (Kemendikbud, 2013). Keterpaduan tersebut dapat tertuang salah satunya melalui modul yang digunakan dalam pembelajaran.

Modul tematik menurut Izzati (2013) adalah pengembangan modul yang mengkaji suatu tema dimana setiap tema terdiri dari beberapa sub tema. Modul E-JAS edutainment 
Pengaruh Modul E-Jas Edutainment terhadap Karakter Peduli Lingkungan dan Tanggung Jawab (Savitri Wanabuliandari, Sekar Dwi Ardianti)

merupakan modul yang penyajiannya disertai dengan kegiatan yang menarik dan menyenangkan melalui jelajah alam sekitar pada sebuah tema pembelajaran yang utuh. Menurut Alimah (2012) kegiatan E-JAS memberikan pengalaman dalam proses belajar peserta didik sehinggaa dapat mengembangkan kemampuan peserta didik melalui fase utama model, yaitu kegiatan eksplorasi,kegiatan interaksi, kegiatan komunikasi dan kegiatan refleksi. Dalam penyusunan Modul E-JAS edutainment disusun dalam format buku, sehingga dapat dengan mudah dipergunakan oleh peserta didik maupun semua kalangan yang berkaitan dengan dunia kependdidikan.

Modul E-JAS edutainment dirancang melaui kegiatan mengemas kembali informasiinformasi yang sebelumnya sudah ada supaya memenuhi standar yang telah ditetapkan. Modul E-JAS edutainment dapat memberikan pengalaman langsung kepada peserta didik sehingga pembelajaran semakin bermakna, selain itu melaui modul E-JAS edutainment peserta didik akan merasakan konsep pembelajaran yang menyenangkan sehingga tidak terasa bahwa mereka sedang belajar yang kaitannya dengan lingkungan. Diharapkan melaui modul E-JAS edutainment karakter peduli terhadap lingkungan serta karakter tanggung jawab terhadap lingkungan dapat meningkat. Berdasarkan latar belakang tersebut diperlukan inovasi baru untuk mengembangkan modul E-JAS edutainment yang dapat membantu peserta didik dalam menumbuhkan karakter tanggung jawab dan peduli lingkungan.

Dalam penelitian ini rumusan masalahnya adalah (1) apakah ada perngaruh penggunaan modul E-JAS edutainment terhadap karakter peduli lingkungan?, dan (2) apakah ada perngaruh penggunaan modul E-JAS edutainment terhadap karakter tanggung jawab?. Berdasarkan rumusan masalah tersebut, maka tujuan dari dilakukannya penelitian ini adalah untuk mengetahui (1) pengaruh penggunaan modul E-JAS edutainment terhadap karakter peduli lingkungan, dan (2) pengaruh penggunaan modul E-JAS edutainment terhadap karakter tanggung jawab. Manfaat dari penelitian yang dilakukan yaitu (1) dapat menambah referensi bagi dunia pendidikan, terutama dalam hal mengkaji karakter peduli lingkungan serta karakter tanggung jawab pada peserta didik, dan (2) memberi masukan bagi guru tentang penggunaan modul E-JAS edutainment merupakan salah satu alternatif dalam meningkatkan karakter peduli lingkungan serta karakter tanggung jawabpada peserta didik.

\section{KAJIAN PUSTAKA Modul E-JAS Edutainment}

Menurut Arum (2016: 240) Modul merupakan satu jenis bahan ajar yang disajikan dalam bentuk sistematis untuk mencapai tujuan dan kompetensi tertentu. Menurut Daryanto (2013) suatu modul dikategorikan menarik serta baik jika terdapat 5 kategori yaitu self instruction, self contained, stand alone, adaptive, dan user friendly. Modul dapat membantu peserta didik untuk belajar secara individu. Sungkono (2009) juga berpendapat sama yaitu bahwa pada dasarnya melaui penggunaan modul, peserta didik dapat belajar secara mandiri maupun kelompok. Hal ini berarti bahwa melalui penggunaan modul akan mengurangi peran guru yang berakibat peserta didik lebih aktif. Selain itu, modul yang dikembangkan hendaknya dibuat dengan bahasa yang baik, menarik, dan disajikan dengan gambar agar meningkatkan pemahaman peserta didik. Keuntungan menggunakan modul adalah memberikan kesempatan peserta didik untuk menemukan sendiri kekurangan dan kesalahan pada saat pembelajaran melalui evaluasi yang diberikan.

Dalam penelitian yang dilakukan modul yang dikembangkan adalah modul $E$-JAS edutainment. Pengembangan modul E-JAS edutainment menggunakan kurikulum 2013. Izzati (2013) menjelaskan bahwa pengembangan modul yang mengkaji suatu tema dimana setiap tema terdiri dari beberapa sub tema. Menurut Arum, dkk (2016: 243) melalui pembelajaran tematik peserta didik dihadapkan pada pengetahuan ang tidak seotong-potong sehingga dalam proses pembelajaran peserta didik mampu memahami materi maupun konsep 
secara utuh. Edutainment sendiri asal mulanya dari kata education dan entertainment. Education berarti berhubungan dengan pendidikan, sedangkan entertainment berarti berkaitan dengan hiburan. Sedangkan edutainment sendiri dari segi bahasa dapat diartikan sebagai pendidikan yang dikemas dengan menyenangkan/ menghibur. Menurut Sutrisno dalam Hamid (2011) salah satu bentuk pembelajaran yang menghibur adalah melalui demonstrasi, main peran, games, humor ataupun berbagai cara agar pembelajaran yang dihasilkan menghibur. Di dalam pembelajaran yang menggunakan pendekatan edutainment, peserta didik diajak untuk berinteraksi dengan lingkungan dengan memasukkan materi dalam bentuk hiburan misalnya musik, multimedia, video games, acara televisi, ataupun kegiatan di alam bebas. Penelitian dari Taufiq, dkk (2014) menunjukkan bahwa melalui pendekatan Edutainment hasil belajar dan karakter peduli lingkungan meningkat. Model pembelajaran $E$ JAS merupakan model pembelajaran yang kegiatannya berupa memberikan pengalaman dalam proses belajar peserta didik sehinggaa dapat mengembangkan kemampuan peserta didik melalui fase utama model, yaitu kegiatan eksplorasi,kegiatan interaksi, kegiatan komunikasi dan kegiatan refleksi (Alimah, 2012). Alimah,dkk (2012) melakukan kegiatan penelitian tentang kejadian di alam sekitar melalui aktivitas peserta didik dengan menggunakan konsep pembelajaran kontektual serta aktif, dimana penelitian tersebut memberikan hasil bahwa Experiential Jelajah Alam Sekitar (EJAS) merupakan model pembelajaran kegiatannya mengeksplorasi langsung suatu obyek belajar dari mahasiswa dengan cara memberikan pengalaman yang lebih bermakna bagi mahasiswa serta pembelajaran yang dilakukan tidak hanya di dalam kelas sehingga menjadi lebih menghibur. Menurut Ardianti (2017) menyatakan bahwa melalui pembelajaran E-JAS terjadi peningkatan secara signifikan pada karakter peduli lingkungan serta karakter tanggung jawab peserta didik.

Modul E-JAS edutainment merupakan bahan ajar mandiri dengan menggunakan tema yang mengikat KI, KD, dan mata pelajaran menjadi satu kesatuan utuh dengan menerapkan sintaks pembelajaran jelajah alam sekitar yang menarik dan menyenangkan. Kegiatan dalam modul E-JAS edutainment bersifat menyenangkan karena menggunakan tema, inkuiri dan permainan yang dapat mendidik peserta didik. Diharapkan ada pengaruh modul $E$-JAS edutainment terhadap karakter peduli terhadap lingkungan serta karakter tanggung jawab terhadap lingkungan, karena :1) dapat membuat peserta didik lebih senang serta membuat tidak terasa sedang belajar, 2) terjadi komunikasi yang baik serta mucul keakraban, 3) membuat pembelajaran lebih bermakna, 4) menggunakan lingkungan sebagai sumber belajarnya, dan 5) menumbuhkan motivasi agar peserta didik dapat lebih giat belajar.

\section{Karakter Peduli Lingkungan dan Karakter Tanggung Jawab}

Karakter peduli terhadap lingkungan adalah sikap maupun tindakan yang berupa kegiatan pencegahan kerusakan lingkungan serta kegiatan memperbaiki kerusakan yang telah terjadi. Dalam Saptono (2011) karakter peduli lingkungan pada peserta didik dapat ditanamkan melalui tindakan yang selalu memperhatikan lingkungan. Melalui penanaman karakter peduli lingkungan, peserta didik mampu memahami bahwa kegiatan pengrusakan lingkungan akan memberikan dampak yang kurang baik terhadap manusia (Yuliati, 2015). Wanabuliandari (2016) menjelaskan bahwa karakter peduli lingkungan dapat ditanamkan melalui kegiatan mengajak peserta didik untuk terjun langsung melihat kondisi lingkungan saat ini. Indikator dari karakter peduli terhadap lingkungan menurut Kemendiknas (2010: 37) adalah untuk kelas 1 sampai kelas 3 difokuskan pada kegiatan buang air besar dan buang air kecil di WC, membuang sampah di tempat sampah, membersihkan sampah berserakan di halaman sekolah, tidak memetik sembarangan bunga di taman sekolah, selalu menjaga kebersihan di sekoah, sedangkan untuk peserta didik kelas 4 dan 5 difokuskan pada kegiatan 
Pengaruh Modul E-Jas Edutainment terhadap Karakter Peduli Lingkungan dan Tanggung Jawab (Savitri Wanabuliandari, Sekar Dwi Ardianti)

membersihkan WC, tempat sampah, lingkungan sekolah, menggunakan tanaman untuk memperindah kelas dan sekolah, serta ikut memelihara taman di halaman sekolah.

Hasan (2010:10) menjelaskan bahwa karakter tanggung jawab adalah sikap atau perilaku seseorang dalam melaksanakan tugas serta kewajibannya baik terhadap Tuhan Yang Maha Esa, diri sendiri, negara maupun lingkungannya. Menurut Ardianti (2017) seorang peserta didik dapat ditanamkan karakter tanggung jawab jika terbiasa bertindak bertanggung jawab terutama terhadap lingkungannya. Menurut Siburian (2012) ada beberapa indikator dalam menanamkan karakter tanggung jawab antara lain (1) perbuatan yang seharusnya dilakukan, (2) merencenakan apa yang dilakukan ke depannya, (3) selalu mencoba melakukan sesuatu, (4) melakukan sesuatu sebaik mungkin, (5) mampu mengendalikan diri terhadap sesuatu, (6) mampu menerapkan disiplin diri yang baik, (7) berpikir dahulu sebelum melakukan sesuatu, (8) mampu menjadi teladan bagi semua orang, dan (9) bertanggungjawab terhadap semua perkataan, sikap maupun tindakan.

\section{Kerangka Berpikir}

Kondisi lingkungan saat ini sangat memprihatinkan dengan tingginya tingkat pencemaran baik udara, air, maupun tanah. Zakiah Darajat dalam Aziz (2013: 11) menjelaskan penanaman karakter peduli terhadap lingkungan serta tanggung jawab terhadap lingkungan yang tidak tertanam dengan baik sejak dini menjadi salah satu penyebab kerusakan lingkungan hidup. Berdasarkan hal tersebut maka perlu adanya peningkatan karakter peduli lingkungan dan tanggung jawab. Selain itu, bahan ajar yang digunakan tidak menyisipkan karakter dalam penyusunannya. Bahan ajar juga belum menampilkan ciri modul yang menarik dan menyenangkan. Bahan ajar yang digunakan lebih bersifat teoritis serta kurangnya kegiatan yang mengajak peserta didik mengenal lingkungan sekitar sehingga menyebabkan kejenuhan dan kurang peduli lingkungan serta tanggung jawab pada peserta didik. Berdasarkan itu perlu adanya inovasi dalam bahan ajar yang digunakan. Pengembangan Modul dilakukan dengan mengkolaborasikan pendekatan tematik edutainment dengan model E-JAS. Dengan demikian, diharapakan terjadi peningkatan secara signifikan karakter peduli terhadap lingkungan serta karakter tanggung jawab terhadap lingkungan melaui pengembangan modul E-JAS edutainment.

\section{Hipotesis Penelitian}

Hipotesis penelitian ini yaitu (1) ada pengaruh penggunaan modul E-JAS edutainment terhadap karakter peduli lingkungan, dan (2) ada pengaruh penggunaan modul $E$-JAS edutainment terhadap karakter tanggung jawab.

\section{METODE PENELITIAN}

Dalam penelitian ini menggunakan jenis penelitian quasi eksperimen. Lokasi dalam penelitian ini berada di SD 2 Jati Kulon, Kecamatan Jati, Kabupaten Kudus. Penelitian ini dilakukan pada semester gasal tahun pelajaran 2017/2018 di SD 2 Jati Kulon. Penelitian ini dilaksanakan pada bulan Maret - juli 2017. Populasi dalam penelitian ini yaitu peserta didik kelas IV SD Negeri di Kabupaten Kudus. Pelaksanaan penelitian menggunakan teknik purposive sampling dalam pengambilan sampel. Sampel di dalam penelitian menggunakan peserta didik di SD 2 Jati Kulon yang berada pada kelas IV. Subyek penelitian ini yaitu peserta didik yang berada di kelas IV pada tahun pelajaran 2017/2018. Dalam pelaksananaan penelitian ini menggunakan rancangan penelitian one group pretest posttest. Teknik pengumpulan data yang digunakan adalah teknik nontes. Teknik nontes digunakan dalam penelitian dengan tujuan untuk mengumpulkan data yang datanya bersifat kualitatif. Teknik yang digunakan yaitu melalui wawancara dan observasi. Wawancara pada penelitian ini 
dilakukan melalui wawancara terstruktur. Wawancara terstruktur dilakukan kepada guru dan peserta didik. Observasi dilakukan untuk mengamati karakter peduli terhadap lingkungan pada peserta didik serta karakter tanggung jawab terhadap lingkungan pada peserta didik. Setelah mendapatkan data, dilakukan analisis data untuk menganalisis pengaruh penggunaan modul E-JAS edutainment pada karakter peduli terhadap lingkungan serta karakter tanggung jawab dengan menggunakan paired samples t-test.

\section{HASIL PENELITIAN DAN PEMBAHASAN Hasil Penelitian}

Penelitian ini dilaksanakan di SD 2 Jati Kulon pada peserta didik kelas IV tahun pelajaran 2017/2018. Hasil penelitian yang diperoleh berupa skor karakter peduli lingkungan dan tanggung jawab peserta didik. Skor diperoleh berdasarkan hasil observasi terhadap karakter peduli lingkungan peserta didik dan talnggung jawab sebelum pembelajaran menggunakan modul dan setelah pembelajaran menggun/akan modul. Rekapitulasi skor hasil observasi karakter peduli lingkungan dan tanggung jawab peserta didik disajikan dalam Tabel 1. berikut ini.

Tabel 1.

Rekapitulasi Hasil Observasi Karakter Peduli Lingkungan dan Tanggung jawab

\begin{tabular}{cccc}
\hline Karakter & Jenis & Jumlah Peserta Didik & Rata-Rata \\
\hline Peduli Lingkungan & Sebelum & 19 & 51,6 \\
& Sesudah & 19 & 74,2 \\
Tanggung Jawab & Sebelum & 19 & 45,1 \\
& Sesudah & 19 & 73,7 \\
\hline
\end{tabular}

Hasil rekapitulasi di SD 2 Jati Kulon menunjukkan bahwa skor karakter peduli lingkungan peserta didik menunjukkan perbedaan antara sebelum pembelajaran menggunakan modul dan sesudah pembelajaran menggunakan modul. Hal tersebut juga terlihat pada skor tanggung jawab peserta didik sesudah pembelajaran menggunakan modul lebih tinggi dibandingkan dengan sebelum pembelajaran menggunakan modul. Sebelum dilakukan uji pengaruh, peneliti melakukan uji prasyarat terlebih dahulu untuk mengetahui kenormalan data. Dari hasil analisis uji prasyarat dengan menggunakan uji Liliefors didapatkan hasil bahwa karakter peduli terhadap lingkungan pada peserta didik serta karakter tanggung jawab terhadap lingkungan pada peserta didik berdistribusi normal. Selanjutnya Rata-rata skor karakter peduli lingkungan dan tanggung jawab peserta didik diuji secara statistik menggunakan uji paired samples T-test. Uji paired samples T-test dilakukan untuk menganalisis apakah terdapat perbedaan secara statistik antara skor karakter peduli terhadap lingkungan pada peserta didik serta karakter tanggung jawab terhadap lingkungan pada peserta didik sebelum dan sesudah pembelajaran menggunakan modul E-JAS Edutainment. Berikut ini adalah hasil uji pengaruh untuk karakter peduli lingkungan peserta didik.

Hipotesis:

$\mathrm{H}_{0}: \mu_{1}-\mu_{2}=0$ (rata-rata tes akhir sama dengan rata-rata tes awal artinya tidak ada pengaruh modul E-JAS Edutainment terhadap karakter peduli terhadap lingkungan)

$\mathrm{H}_{1}: \mu_{1}-\mu_{2} \neq 0$ (rata-rata tes akhir tidak sama dengan rata-rata tes awal artinya ada pengaruh modul E-JAS Edutainment terhadap karakter peduli terhadap lingkungan) 
Pengaruh Modul E-Jas Edutainment terhadap Karakter Peduli Lingkungan dan Tanggung Jawab (Savitri Wanabuliandari, Sekar Dwi Ardianti)

Tabel 2.

Hasil Uji Pengaruh Modul E-JAS edutainment Terhadap Karakter Peduli Lingkungan

\begin{tabular}{ccc}
\hline $\mathrm{t}_{\text {hitung }}$ & $\mathrm{t}_{\text {tabel }}$ & Keterangan \\
\hline 9,43 & 2,10 & $\mathrm{H}_{0}$ ditolak \\
\hline
\end{tabular}

Hasil uji-t menunjukkan bahwa nilai $t_{\text {hitung }} 9,43>t_{\text {tabel }} 2,10$, maka Ho ditolak maka rata-rata tes akhir berbeda dengan rata-rata tes awal artinya ada pengaruh modul $E$-JAS Edutainment terhadap karakter peduli lingkungan. Berikut ini adalah hasil uji pengaruh untuk karakter tanggung jawab.

Hipotesis:

$\mathrm{H}_{0}: \mu_{1}-\mu_{2}=0$ (rata-rata tes akhir sama dengan rata-rata tes awal artinya tidak ada pengaruh modul E-JAS Edutainment terhadap karakter tanggung jawab)

$\mathrm{H}_{1}: \mu_{1}-\mu_{2} \neq 0$ (rata-rata tes akhir tidak sama dengan rata-rata tes awal artinya ada pengaruh modul E-JAS Edutainment terhadap karakter tanggung jawab)

Tabel 3.

Hasil Uji Pengaruh Modul E-JAS edutainment Terhadap Karakter Tanggung Jawab

\begin{tabular}{ccc}
\hline $\mathrm{t}_{\text {hitung }}$ & $\mathrm{t}_{\text {tabel }}$ & Keterangan \\
\hline 14,39 & 2,10 & $\mathrm{H}_{0}$ ditolak \\
\hline
\end{tabular}

Hasil uji-t menunjukkan bahwa nilai $t_{\text {hitung }} 14,39>t_{\text {tabel }} 2,10$, maka Ho ditolak maka rata-rata tes akhir berbeda dengan rata-rata tes awal artinya ada pengaruh modul E-JAS edutainment terhadap karakter tanggung jawab.

\section{Pembahasan}

Hasil uji-t menunjukkan bahwa terdapat pengaruh penggunaan modul E-JAS edutainment terhadap karakter peduli lingkungan dan tanggung jawab peserta didik. Penggunaan modul E-JAS edutainment memberikan dampak positif pada karakter peduli terhadap lingkungan peserta didik serta karakter tanggung jawab peserta didik. Hal tersebut dikarenakan modul E-JAS edutainment dilengkapi dengan kegiatan yang mengajak peserta didik secara langsung untuk melakukan pembelajaran secara nyata di lingkungan sekolah. Kondisi tersebut dapat memberikan pengalaman kepada peserta didik untuk mengetahui lingkungan secara langsung sehingga diharapkan peserta didik memperoleh pengetahuan dan wawasan yang luas dari lingkungan. Ardianti (2017) menyatakan bahwa kegiatan pembelajaran yang dilakukan secara langsung di lingkungan akan memberikan pengalaman secara langsung kepada peserta didik sehingga peserta didik dapat mengambil keputusan tentang sikap yang baik terhadap kondisi yang terjadi di lingkungan. Peserta didik akan terbiasa memberikan perilaku yang baik terhadap lingkungan sehingga dapat meningkatkan karakter peduli lingkungan peserta didik. Kegiatan eksplorasi yang terdapat dalam modul $E$ JAS edutainment mempermudah guru dalam membiasakan perilaku baik terhadap lingkungan. Sari (2013) dalam penelitiannya menjelaskan bahwa instansi pendidikan dapat menerapkan kegiatan jelajah alam sekitar di pembelajarandalam rangka menanamkan karakter pada peserta didik. Pembelajaran dengan melibatkan peserta didik secara langsung ke dalam lingkungan akan mempermudah guru dalam menanankam pendidikan karakter, khususnya karakter peduli lingkungan dan tanggung jawab peserta didik.

Modul E-JAS edutainment yang digunakan juga dilengkapi dengan kegiatan praktikum sederhana bagi peserta didik. Kegiatan praktikum sederhana memberikan pembelajaran kepada peserta didik untuk menyiapkan setiap alat dan bahan dengan baik serta dapat mengembalikannya dalam kondisi yang baik. Hal tersebut melatih peserta didik untuk 
bertanggung jawab terhadap apa yang dilakukan. Kegiatan praktikum yang dilakukan di lingkungan secara langsung dapat menanamkan karakter peduli lingkungan dan tanggung jawab peserta didik. Selain itu modul E-JAS edutainment dapat mengajak peserta didik untuk belajar dalam kondisi pembelajaran yang menghibur. Peserta didik dapat mengekspresikan pendapat dan pengalamannya dalam modul E-JAS edutainment. Pembelajaran dengan modul E-JAS edutainment menyajikan pembelajaran dengan prinsip menyenangkan sehinggan dapat mengaktifkan peserta didik dalam pembelajaran dan tidak membuat peserta didik menjadi jenuh. Hamid (2011) menyatakan bahwa pembelajaran dengan pendekatan edutainment menyajikan pembelajaran yang menyenangkan dan tidak membosankan. Pemanfaatan lingkungan sebagai sumber belajar yang dimasukkan dalam modul E-JAS edutainment dapat memberikan variasi pembelajaran bagi peserya didik. Uno (2015) menyatakan bahwa pembelajaran dengan memanfaatkan lingkungan yang berbeda dengan biasanya dapat meningkatkan motivasi peserta didik. Peserta didik merasa nyaman dalam pembelajaran dan tidak mengalami kejenuhan dalam kegiatan belajarnya. Dengan demikian, melalui penggunaan modul E-JAS edutainment dapat memengaruhi karakter peduli lingkungan dan tanggung jawab peserta didik.

\section{SIMPULAN DAN SARAN}

Modul yang dibuat dalam kegiatan penelitian ini yaitu modul E-JAS edutainment. Modul dapat membantu peserta didik untuk belajar secara individu dan mengurangi peran guru yang berakibat peserta didik lebih aktif. Melalui pembelajaran tematik membuat peserta didik belajar secara menyeluruh sehingga peserta didik mampu memahami materi maupun konsep secara utuh. Selain itu, dengan menggunakan pendekatan edutainment pembelajaran akan lebih menyenangkan. Edutainment menggabungkan antara materi dengan hiburan agar lebih akrab di telinga peserta didik sehingga terjadi interaksi sosial pada peserta didik. Selanjutnya model pembelajaran E-JAS juga dikembangkan dalam modul tujuannya agar peserta didik melakukan eksplorasi langsung dengan obyek belajar serta memberikan pengalaman yang bermakna bagi peserta didik sehingga menjadi lebih menyenangkan. Modul E-JAS edutainment merupakan bahan ajar mandiri dengan menggunakan tema yang mengikat KI, KD, dan mata pelajaran menjadi satu kesatuan utuh dengan menerapkan sintaks pembelajaran jelajah alam sekitar yang menarik dan menyenangkan. Pada penelitian ini didaptkan beberapa kesimpulan yaitu (1) ada pengaruh penggunaan modul E-JAS edutainment terhadap karakter peduli lingkungan, dan (2) ada pengaruh penggunaan modul E-JAS edutainment terhadap karakter tanggung jawab.

Saran yang dapat peneliti sampaikan adalah (1) dalam menggunakan modul E-JAS edutainment guru hendaknya memperhatikan kondisi kelas dengan baik dan memperhatikan waktu yang tersedia sehingga karakter peduli lingkungan dan tanggung jawab dapat muncul, (2) modul E-JAS edutainment dapat dijadikan sebagai buku pegangan guru untuk menyampaikan materi, dan (3) Pengembangan modul E-JAS edutainment dapat dikembangkan pada peserta didik slow learner.

\section{UCAPAN TERIMAKASIH}

Penulis mengucapkan terimakasih kepada SD 2 Jati Kulon Kecamatan Jati Kabupaten Kudus yang telah memberikan ijin untuk melaksanakan kegiatan penelitian. Selanjutnya, terimakasih kepada Direktorat Jenderal Penguatan Riset dan Pengembangan, Kementerian Riset, Teknologi dan Pendidikan Tinggi yang telah mendanai kegiatan penelitian yang peneliti lakukan dengan nomor kontrak 95/Lemlit.UMK/B.07.02/IV/2017. 
Pengaruh Modul E-Jas Edutainment terhadap Karakter Peduli Lingkungan dan Tanggung Jawab (Savitri Wanabuliandari, Sekar Dwi Ardianti)

\section{DAFTAR PUSTAKA}

Akbar, S. 2010. Model Pembelajaran Nilai Karakter Berbasis Nilai-nilai Kehidupan Sekolah Dasar, Jurnal Ilmu Pendidikan, (1),46-54.

Alimah, S. 2012. Pengembangan Pembelajaran Experiential Jelajah Alam Sekitar pada Mata Kuliah Biologi. Proceeding Seminar Nasional MIPA Unnes: Peran MIPA dalam Meningkatkan Kualitas Hidup dan Pengembangan Pendidikan Karakter. ISBN: 978602-18553-2-4 hal 594-600

Ardianti, S. D., Wanabuliandari, S., \& Rahardjo, S. (2017). Peningkatan Perilaku Peduli Lingkungan dan Tanggung Jawab Siswa melalui Model EJAS Dengan Pendekatan Science Edutainment. Jurnal Pendidikan Dasar, 4(1),1-7.

Arum, T. S., \& Wahyudi. 2016. Pengembangan Modul Pembelajaran Tematik Integratif Subtema Hubungan Makhluk Hidup Dalam Ekosistem Pendekatan Saintifik Untuk Kelas 5 SD. Scholaria, 6(3), 239-250.

Aziz, Erwati. 2013. Upaya Pelestarian Lingkungan Hidup Melalui Pendidikan Islam. Yogyakarta: Pustaka Pelajar

Barbier, Edward B. 2015. Nature and wealth Overcoming Environmental Scarcity and Inequality. United Kingdom : Palgrave Macmillan UK

Blacksmith Institute and Green Cross Switzerland. 2013. The Top Ten Toxic Threats: Cleanup, Progress, and Ongoing Challenges. New York. (http://www.blacksmithinstitute.org/new-report-cites-the-world-s-worst-pollutedplaces.html)

Daryanto. 2013. Menyusun Modul. Yogyakarta: Gava Media.

Hamid, Sholeh. 2011. Metode Edutainment. Yogyakarta: Diva Press

Izzati N., Hindarto N., \& Pamelasari S. D. 2013. Pengembangan Modul Tematik dan Inovatif Berkarakter pada Tema Pencemaran Lingkungan untuk Siswa Kelas VII SMP. Jurnal Pendidikan IPA Indonesia, 2(2), 183-188.

Kementrian Pendidikan Nasional, Badan Penelitian dan Pengembangan Pusat Kurikulum. 2010. Bahan Pelatihan Penguatan Metodologi Pembelajaran 127 Berdasarkan NilaiNilai Budaya Untuk Membentuk Daya Saing Dan Karakter Bangsa. Pengembangan Pendidikan dan Karakter Bangsa. Jakarta: Kemendiknas.

Kementrian Pendidikan Nasional, Badan Penelitian dan Pengembangan Pusat Kurikulum. 2010. Pengembangan Pendidikan Budaya Dan Karakter Bangsa. Jakarta: Kemendiknas.

Kementrian Pendidikan Nasional, Badan Penelitian dan Pengembangan Pusat Kurikulum. 2013. Diklat Guru Dalam Rangka Implementasi Kurikulum 2013. Jakarta: Kemendikbud.

Marlina, Reni., Hardigaluh,Basuki., dan Yokhebed. 2015. Pengembangan Modul Pengetahuan Lingkungan erbasis Potensi Loal Untuk Menumbuhkan Sikap Peduli Lingkungan Mahasiswa Pendidikan Biologi. Jurnal Pengajaran MIPA, 20(1), 94-99.

Parmin, \& Peniati, E. 2012. Pengembangan Modul Mata Kuliah Strategi Belajar Mengajar IPA Berbasis Hasil Penelitian Pembelajaran. Jurnal Pendidikan IPA Indonesia, 1(1), $8-15$ 
Saptono. 2011. Dimensi-dimensi Pendidikan Karakter, Wawasan, Strategi, dan Lengah Praktis. Salatiga: Erlangga

Sari, YK., Susilowati, S.M.E., \& Ridlo, S. 2013. Efektivitas Penerapan Metode Quantum Teaching Pada Pendekatan Jelajah Alam Sekitar (JAS) Berbasis Karakter dan Konservasi. Unnes Science Education Journal, 2(2) 166-172.

Siburian, P. 2012. Penanaman dan Implementasi Nilai Karakter Tanggung Jawab. Jurnal Paradikma, 5 (1), 2-19.

Sungkono. 2009. Pengembangan Bahan Ajar. Yogyakarta: UNY Press.

Taufiq, D., dan Widiyatmoko. 2014. Pengembangan Media Pembelajaran IPA Terpadu Berkarakter Peduli Lingkungan Tema "KONSERVASI" Berpendekatan ScienceEditainment. Jurnal Pendidikan IPA, 3(2), 140-145.

Uno, H. B., \& Mohamad, N. 2015. Belajar dengan Pendekatan PAILKEM. Jakarta : PT BumiAksara.

Uyoh, S. 2010. Pedagogik (Ilmu Mendidik). Bandung: Alfabeta

Wanabuliandari, S., Ardianti, S., D., \& Rahardjo, S.,. 2016. Implementasi Model EJAS Berbasis Mathematic Edutainment Untuk Meningkatkan Prestasi Belajar dan Prilaku Kepedulian Terhadap Lingkungan. Jurnal EDUMA, 5 (2), 34-41.

Yuliati, T. \& Martuti, N. K. T. 2015. Efektifitas Penerapan Model Field Trip Untuk Meningkatkan Hasil Belajar dan Kepedulian Siswa Terhadap Lingkungan. Jurnal Pendidikan Matematika dan Sains, 3 (1), 39-48. 